\title{
Kako do vizije izobraževanja odraslih
}

Zadniih nekaj let z zanimanjem spremljam nova odkritja in spoznanja na področju andragogike in v niej sorodnih vedah. Ni kaj, kljub neustrezni podpori pristojnih uladnih institucij (finančni, organizacijski ...), je strokounjakom in raziskovalcem uspelo naš koncept in izkušnje povzdigniti na mednarodno raven. Vsi vključeni subjekti so $v$ zadnjib nekaj letih zgradili mrežo, na podlagi katere so nastale nove oblike organizacij, ki omogočajo različne oblike izobraževanja, usposablianja, raziskovanja in osvešcanja za različne ciljne skupine starejšib in mlajših. Model je posnemanja ureden tudi za nekatere sosednje države. Toda ali se takšen model ujema z vizijo izobraževanja odraslih v Sloveniji? Dalie, ali sploh imamo vizijo izobraževanja? Mar velja pri tem posnemati zgolj vizijo izobraževanja držav OECD ali morda držav Evropske skupnosti? Ne, nikakor se ne smemo podrejati njibovim že uveljavljenim »receptom in modelom «. Pomeni, da moramo $v$ prvi ursti izhajati iz lastnih spoznanj, izkušenj, teženj in želja. Vizija ali zamišljanje podobe izobraževalnega koncepta odraslih v pribodnosti mora izhajati iz nas samih. Na nas je, da to vizijo odkrijemo in definiramo.

Kako naj bi proces odkrivanja vizije izobraževanja odraslih potekal? Predusem se moramo aktivneje usmeriti v raziskovanje (odkrivanje) kvalitativnih podatkov o raziskovanih cilinih skupinab in se malce oddalijti od kvantitativnih metod, ki nam o pričakovanih rezultatih izobraževanja in usposablianja premalo povedo. Nazoren primer so podatki o naraščanju števila diplomantov na obeh naših univerzah in po drugi strani strma rast stevila brezposelnih diplomantov. Marsikdo se bo vprašal, mar moramo res use meriti po poupraševanju in ponudbi na trgu? Vsekakor ne! Toda izobraževalna »strategija « nedvoumno ne izhaja iz potreb in želja posameznika, njegovega okolja, kaj šele iz njegovih pričakovanj. V razvitih državah in na razuitih trgih deloune sile (ZDA, Kanada, Avstralija, Irska, Danska ...) so pred približno desetimi leti začeli pri izobraževanju odraslih uvajati koncept, ki je vsekakor vreden delnega posnemanja. Pri usposablianju odraslih so se pretežno usmerili $v$ koncept Training by Design, kar pomeni, da so vso promocijo usmerili k osveščanju posameznika, ki si končno labko pomaga le sam, če ima lastne potrebe, življenjske cilje in motivacijo za nove dosežke. Država ponuja izzive, spodbuja podjetništvo.

Analize v suetu in pri nas kažejo, da je prišlo do velikanskega poupraševanja po praktičnih znanjih $v$ smislu Kako naredim to ali kako ustvarim ono. $V$ eni izmed držav OECD-ja so ugotovili, da tudi sistem vseživljenjskega učenja ne prinaša dovolj učin-
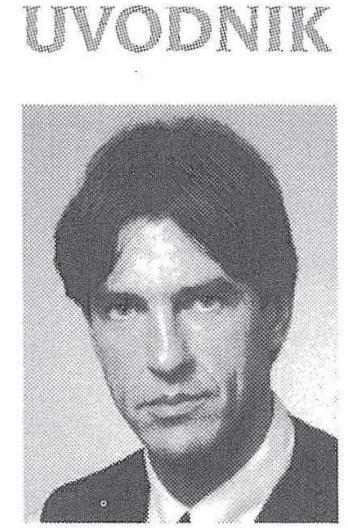

Mag. Jordan Berginc

Visoka šola za podjetništvo Portorož

\section{»Ne bodimo} vsi žrtve lastne kulture, na probleme glejmo bolj ustvarjalno! « J. B. kovitih rezultatov, kot On the Job Training, $v$ katerega se vključujejo delazmožni ljudje. Zatorej je najpomembnejša zavzetost posameznika za določeno aktivnost. Če je njegova zavzetost velika, bo tudi usposablianje sprejel z navdušenjem. Boljše rezultate dosegajo tam, kjer posameznik ve, zakaj nekaj potrebuje.

Dejali boste - nič novega, česar ne bi že poznali! Žal praksa potriuje prav nasprotno. Večini ciljnim skupinam odraslih se ponuja sistem izobraževanja in znanj, ki vsekakor ne spodbuja (navdušuje), temveč v posamezniku vzbuja dvome o koristnosti ponujenega znanja. Poleg tega useporprek zanikujemo pričakovanja vkliučenih v izobraževalni proces. Mar ni v današnjem univerzitetnem sistemu vse preveč transmisije "specializiranih "znanj in vse premalo razvijanja sposobnosti, spretnosti in talenta študentov? Ugotovlieno je, da začne motivacija za lastne ambicije pri študentih upadati, ko stopajo $v$ drugi letnik studija na dodiplomski ravni. Zakaj odklanjamo njihova pričakovanja? Zakaj se vedno zadovolijmo s povprečnostio na tem področju? Komparativne analize kvantitativnih podatkov z deželami Evropske skupnosti nam kažejo čedalje večji razkorak $v$ stopnji izobraževanja in ustvarjane dodane vrednosti na prebivalca. Ni razloga za preplah, toda z gotovostjo labko trdimo, da je koncept izobraževanja odraslih v krizi.

$D a$, vizija nam manjka. Brez vizije ni orientacijse točke. Ali kot bi se temu dejalo: noben veter ni ugoden ladji brez cilja. Do vizije si bomo pomagali tudi z domišlijo, ki je nedvomno povezana $z$ našim ustvarjalnim potencialom. Naj vam povem, kaj je pripomnil neki ameriški profesor ob najini razpravi o neizkorišcenih potencialih domačih talentou? Dejal je: »Ljudje v tako majhni deželi, kot je Slovenija, se zagotovo ne bodo mogli kosati z raziskovalnimi dosežki vrhunskib tebnologij, ki jih financira ogromen, predusem tuj kapital. Labko pa se izkažete s svojimi avtentičnimi pristopi, prednostmi, navadami in potrebami, ki pa se morajo navezovati na ustvarjalno področje. Pomnite, prihajajoče stoletje je stoletje ustvarjalnosti in inovativnosti v razvoju človeštva. Vsaka dežela bo labko konkurenčna samo toliko, kolikor bodo ustvarjalni in inovativni njeni ljudje. Prehajamo v ekonomijo ustvarjalnosti. «Ob tej izjavi se človek kar malce zamisli. Kaj je z našim ustvarjalnim potencialom, zakaj ga ne znamo dovolj spodbujati in ga produktivno usmerjati? Kako ga lahko spodbujamo z izobraževanjem? A to je že druga zgodba. Za konec pa še ta stara misel: "Če želiš premakniti goro, začni prenašati kamenčke! « 